\title{
強力超音波振動系専用の最適設計 システムの開発*
}

清 水弘幸** 佐田登志夫***

Development of the Optimal Design System

for High-Intensity Ultrasonic System

Hiroyuki Shimizu and Toshio Sata

\begin{abstract}
This paper describes the concepts and the applications of the design system which is developed to carry out optimal design for the high-intensity ultrasonic system. The design system consists of an optimizing program based on a simultaneous search plan and data bases in which data sets, vibration analysis programs by the finite element method, and other programs are included. The optimal value satisfied with design specifications is determined by means of the optimizing program. In this paper, the design of a solid horn that is one in several components of the high-intensity ultrasonic system is presented for an example of applications of the design system. The solid horn with a large diameter that has been produced in the rule of trial and error up to now is developed in a short time by the generative approach in the design system. The success in the applications confirms the practicality of the design system.
\end{abstract}

Key words : optimal design system, high-intensity ultrasonic system, optimizing program, vibration analysis program, solid horn

\section{1. ま えがき}

超音波加工や超音波溶接などの超音波エネルギーを 動力的に利用する強力超音波応用分野がある。近年, この分野でも，要求される製品の多様化により多種少 量生産の占める割合が急激に増加し, 製品開発時間の 短縮化に迫られている。ところで，この分野の中心的 技術は, 振動子, 固体ホーン, 支持体および工具によ り構成される超音波振動系を，いかに最適に設計する かにある。この振動系の設計の良否が，そのまま，製 品の性能の良否を決定してしまうので, この振動系の 設計に多くの時間を費やして試行錯誤で最適な設計値 を求めている，そこで，この設計時間の短縮が早急に 迫られている。

超音波振動系の最適な設計を行扣らとするとき, 数 理計画法に基づく最適設計法1の適用が考学られる が, この振動系に対する数学モデル化の困難さにより, その適用は難しい，従って，最適設計性を考慮した強 力超音波振動系専用の設計システムの開発が望まれ

$*$ 原稿受付 昭和 62 年 7 月 10 日. 昭和 61 年度精密工学会 秋季大会学術講演会（昭和 61 年 10 月 12 日）にて発表

** 正会員 電気通信大学電気通信学部（調布市調布 $斤$ 丘 1-5-1)

*** 正会 員 理化学研究所 (和光市広沢 2-1)
る.

そこで, 本研究では, 既に開発した有限要素法によ る強力超音波振動系の振動解析専用プログラム 2) と, 本文で開発した簡易な最適化プログラムとを用いて, 最適設計システムを開発した，本文中では，本最適設 計システムの概念と適用例について述べる.

\section{2. 設計システムの概念}

\section{1 設計法の定式化}

形状寸法などの設計諸元よりなる集合を $D$, 固有振 動数などの属性諸元よりなる集合を $P$ とすると, $P$ の 各要素 $P_{i}$ は,

$$
P_{i}=\mathrm{fc}_{i}(D)
$$

と求められる.ここで, 記号 fc は集合 $D$ の各要素す べてを引き数とする有限要素法による強力超音波振動 系の振動解析専用プログラム (以下, FEM 専用プログ ラムと呼ぶ)での演算を意味する ${ }^{3)}$. いま, 制約仕様と 目標仕様が与えられたときの設計を考える. 制約仕様 は, 設計諸元と属性諸元とへの制約があるので, 制約 諸元からなる集合を $C=\left[C_{1}, C_{2}\right]$ とすると，

$$
C_{1} \cong D, \quad C_{2} \cong P
$$

なる関係が成立し，制約仕様を

$$
C_{m} \leqq \bar{C}_{m} \quad(m=1,2)
$$


と表すことができる.ここで，集合 $\bar{C}_{m}$ は，集合 $C_{m}$ の各要素に対して制約を定 める上限値よりなる集合である。式 (3) を満たす集合 $C_{m}$ の領域を，一般に制約 領域と呼んでいる。一方，目標仕様は， 一般には設計される構造物の重量とか価 格を最小にすることを目標にしている. しかし，本研究で扱う強力超音波振動采 の設計に対しては, 重量や価格は重要で なく,むしろ，振動系の性能が重要とな る. この振動系の性能を表す諸元は, 属 性諸元に含まれるので目標仕様の定式化 は次のように表現できる，すなわち，目 標諸元よりなる集合を $A$ とすると，

$$
A \cong P
$$

なる関係が成立し，集合 $A$ の各要素を $A_{i}$ とするとき，目標仕様を

$$
\mathrm{fc}_{i}\left(D_{0}\right)=\operatorname{Min}\left[A_{i}\right]
$$

と表現できる.この式（5）は，式（1）よ り, $D=D_{0}$ のとき $A_{i}$ を最小 (以下で, 最 小を最大と考えても同じである）にで き，目標值を $A_{i}$ の最小に抏いたとき $D_{0}$ が最適設計値であることを意味する.

本研究での設計システムの基本的概念 は，式 (3) の制約条件下で式 (5) の方程 式を満たす解 $D_{0}$ を, FEM 専用プログラ ムの演算結果から, 次項で述べる最適化 プログラムにより，自動的に選択するこ とにある。

\section{2 最適化アルゴリズム}

強力超音波振動系の FEM 専用プログ ラムによる振動解析の演算規模は, 一般 の構造物のそれに比べて小さいので, 式 （5）の最適解 $D_{0}$ を求める最適化アルゴ リズムに，一斉探索方式を適用すること ができる、このアルゴリズムは，総当た りによる数值の大小を判断して最小値を 求める簡単なものであり，図 1 にその考 えを示す。

まず，設計，制約捻よび目標の各諸元によりなる集 合 $D, C$ 扎よび $A$ の定義を行い，数値の大小を判断す るとき使用する作業用の各集合の初期設定を行う。そ して，探索すべきモデルの総数 $p$ を設定する．次に， モデル番号 $j$ に対する設計諸元の設定 $\left(D=D_{j}\right)$ を行 い, FEM 専用プログラムの演算結果から属性諸元 $P_{j}$ を決め $\left(P=P_{j}\right)$, 制約諸元 $C_{j}$ 打よび目標諸元 $A_{j}$ を

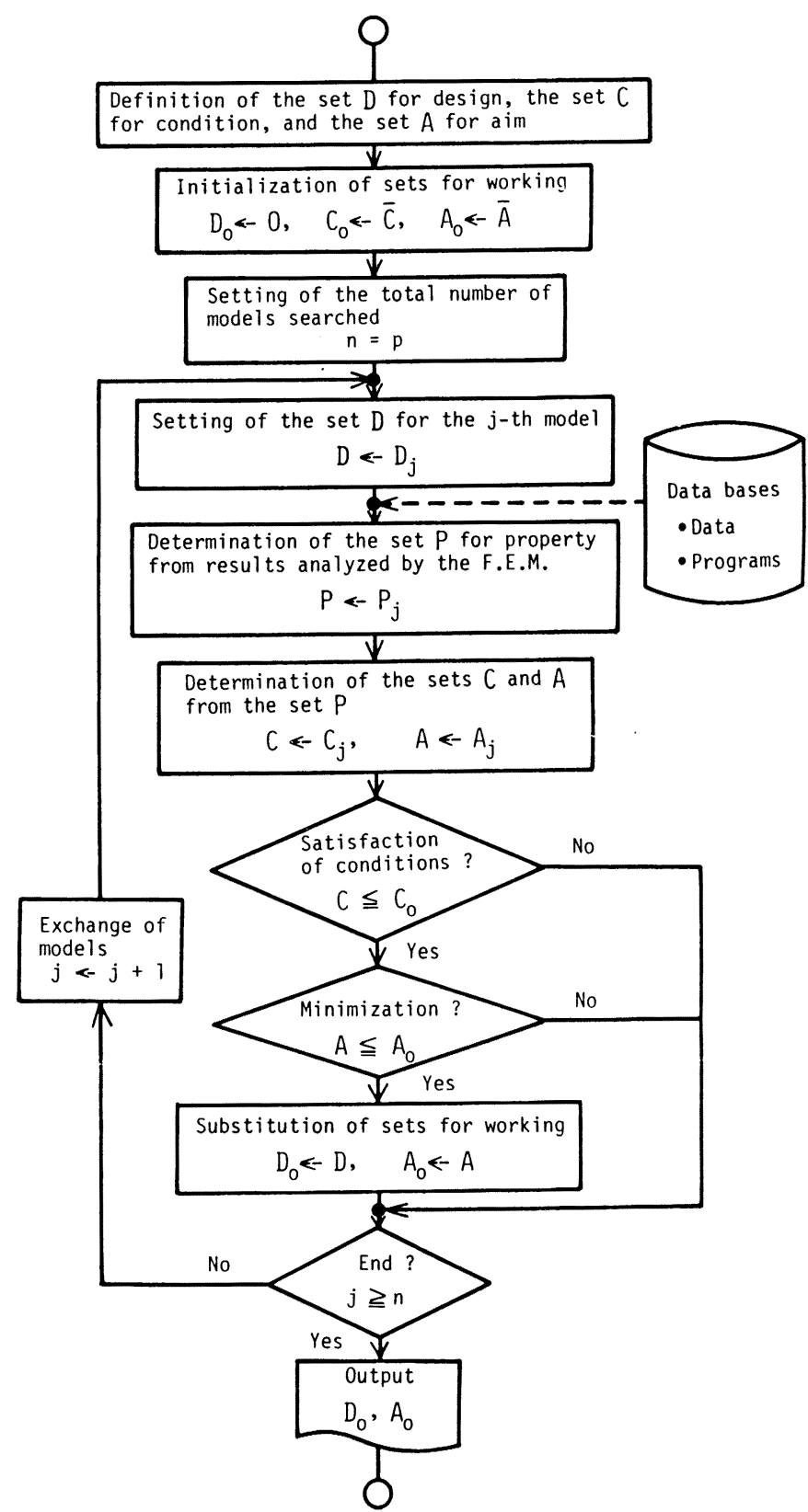

Fig. 1 Basic algorithm for the optimizing program

属性諸元 $P_{j}$ より決める $\left(C=C_{j}, A=A_{j}\right)$. そして, 制約諸元 $C_{j}$ に対して, 式 (3) の制約条件が成立する かを判定し，式（5）の最小值の判定を行ら。このルー チンをモデル総数 $p$ の回数だけ行い, 最終的に制的領 域内で最小値を求め, その值と最適設計値とを出力す ることができる.もし，最小値を求めることができな い場合（初期設定値が厳しく制約領域が存在しないこ とによる）には，初期設定值に対する最適設計値が存 


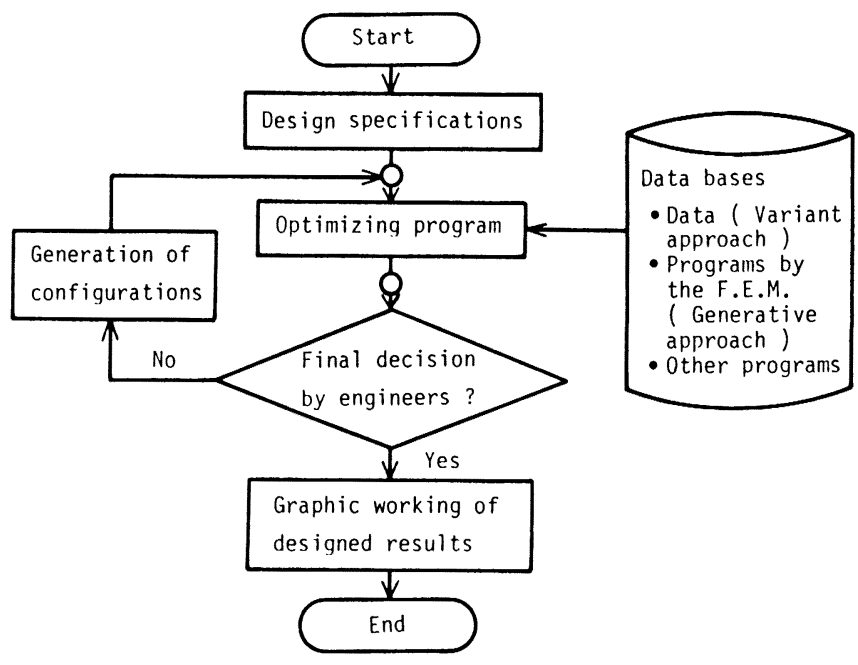

Fig. 2 Flowchart of the optimal design system for the highintensity ultrasonic system

在せず，各諸元の初期設定値が出力される．そして， この場合，設計者の判断により新たに制約諸元あるい は目標諸元を再設定し，最適設計を行うことができる.

\section{3 設計システムの構成}

開発した最適設計システムのシステム構成の概略を 図 2 に示寸，与兄られた設計仕様に対して，このシス テムでは，まずバリアントアプローチで過去のデータ の集合の中から最適化プログラムにより最適設計值を 探索する，もし，最適設計值が探索できないときには， 設計者の創意工夫に基づくジェネラティブアプローチ を適用して，設計対象物の原形の創造を行い，最適化 プログラムにより最適設計を行うことができる. 最適 設計の結果は, 最終的に設計者の判断により, 図面化 などの情報化作業により表示される.

\section{3. 直径の太い固体ホーンの設計への適用}

次に, 本最適設計システムの適用例として, 強力超 音波振動系の構成要素の一つである固体ホーンの設計 について述べる. 近年, 大出力超音波パワーの要求に 伴い, 固体ホーンの端面に数個の振動子を接合する方 式が採られている。このため, 固体ホーンの直径は, 從来の一次元設計法（棒の縦振動方程式に基づく設計 法) が成立すると考兄られていた範囲 $d_{1} \leqq \lambda / 4\left(d_{1}:\right.$ 太 い端面の直径, $\lambda$ : 波長) をはるかに越えて太くなっ た．この直径の太い固体ホーンは，その設計方法もな く，長時間を要して試行錯誤で製作されていた。この 直径の太い固体ホーンを, 本設計システムは以下のよ らに短時間で設計可能とした。

\section{1 設計諸元および属性諸元の説明}

形状関数 $g(z)$ で外形が表現される,軸対 称構造の固体ホーンの寸法座標拄よび振動 モードの形（破線）を図 3 に示す。ホーン 全長を $L, 太$ 端面直径を $d_{1}$, 細い端面直 径を $d_{2}$ とする。また，ホーンの太い端面中 心および外周での $z$ 方向変位成分を $V_{0}$ お よび $V_{\mathrm{s}}$ とし，細い端面でのそれらを $V_{1}$ 打 よび $V_{\mathrm{T}}$ とする.この固体ホーンの設計諸 元からなる集合 $D$ を,

$$
D=\left[g(z) \text {, 材質, } d_{1} / L, d_{2} / d_{1}\right]
$$

と決める.ここで, 形状関数 $g(z)$ は, 指数, 直線, 双曲線, ステップ抢よび丸み付きス テップなどの関数を示し，材質は鋼掞よび アルミニウム合金などである。また，パラ メータ $d_{1} / L$ および $d_{2} / d_{1}$ は設計変数であ る.

一方，固体ホーンの属性からなる集合 $P$ を， $P=$ [無次元固有振動数 $\alpha L$, ホーン全長 $L$, 太い 端面直径 $d_{1}$, 細い端面直径 $d_{2}$, 振幅拡大率 $\left|V_{1}\right|$ $V_{0} \mid$, 太い端面のピストン運動性 $\left|V_{\mathrm{S}} / V_{0}-1\right|$, 細 い端面のピストン運動性 $\left|V_{\mathrm{T}} / V_{1}-1\right|$, 振動節の $z$ 座標 $z_{n}$, 振動節の $r$ 方向变位成分 $V_{r}$, 最大主 応力 $P_{\mathrm{M}}$ ]

と決める ${ }^{4)}$.この属性諸元の各值は, 式 (1) に示すよう に設計諸元の設定值に対する FEM 専用プログラムの 演算結果より求められる解析値である. 前述の 5 種類 の形状関数の固体ホーンについては，使用頻度も高い ので，すでに FEM 専用プログラムにより演算を行い (要素数 128, 節点数 85 の要素分割モデルでの倍精度 計算, 以下の演算でも同じ), その結果より得た属性諸 元をデータベースに蓄積してある。

\section{2 直径の太い固体ホーンの設計仕様}

実用的観点より与えられた設計仕様は，“共振周波 数 $15 \mathrm{kHz}$, 最大出力 $2.5 \mathrm{~kW}$, 出力端面振幅 $7 \mu \mathrm{m}$, 直

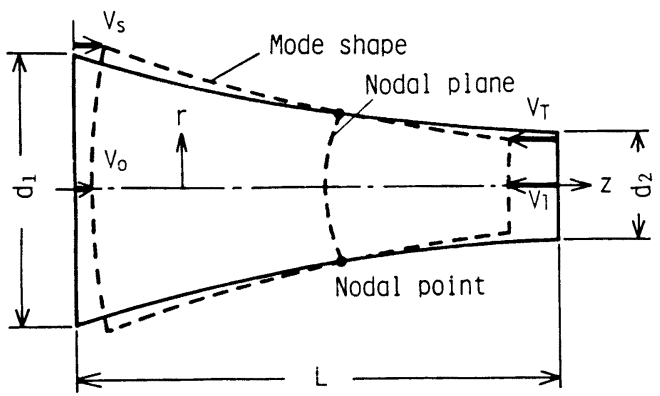

Fig. 3 Geometry and mode shape of a solid horn with an arbitrary cross-sectional shape 
径 $60 \mathrm{~mm}$, 全長 $155 \mathrm{~mm}$ の超音波振動子を 2 個接続す ることができ，太い端面直径に対する細い端面直径の 比が 0.4 である固体ホーンで, 振幅拡大率が 3 以上 4 以内の範囲にあるもの”である.この設計仕様を満た す固体ホーンの最適設計を本設計システムで行らに際 して, 次の点を考慮しなければならない。すなわち, この設計仕様のように 2 個以上の振動子を一つの固体 ホーンに接続するとき, 接続される振動子の負担分担 が等しくなり, 各振動子の出力パワーが平等になるよ らに，両者はピストン運動で結合されねばならない。 このことより, 設計される固体ホーンの太い端面はピ ストン運動性が良く, その直径は 2 個の振動子を全面 で受けるため $120 \mathrm{~mm}$ 以上が必要となる。また，細い 端面も同様に，工具との接合を良好に行えるため，ピ ストン運動する必要がある.

\section{3 バリアントアプローチ}

設計に当たって，まず，図 1 に示すように，設計， 制約抢よび目標の各諸元を定義しなければならない。 このとき，与えられた設計仕様に基づき各諸元が定義 されるが, 定義の仕方は設計者により多少の自由度が ある，以下に，本文での実行例を述べる，まず，前節 で述べた設計仕様に基づき，設計諸元を式（6）で，ま た，制約諸元をホーンのピストン運動性を考慮して，

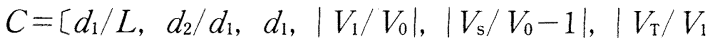
-1 门之定義する。実際の上限値を定めた式 (3) に相 当する制約条件式は，

I. $0.1 \leqq d_{1} / L \leqq 1.0,0.1 \leqq d_{2} / d_{1} \leqq 1.0$

II. $3 \leqq\left|V_{1} / V_{0}\right| \leqq 4,\left|V_{\mathrm{S}} / V_{0}-1\right| \leqq 0.5$,

$$
\left|V_{\mathrm{T}} / V_{1}-1\right| \leqq 0.5,120 \mathrm{~mm}<d_{1}
$$

である.ここで，ピストン運動性が 0.5 以内としたの は, この範囲内で端面のピストン運動性が良く接合に よる問題が生じていない経験に基づくものである. た, 目標諸元をホーンの太い端面の直径 $d_{1}$ とし, 2 個 の振動子がその端面に十分良く取り付けられる寸法々 して $d_{1}=125 \mathrm{~mm}$ となることを設計目標とするので, 式 (5) に示す目標仕様の定式化は,

$$
\text { fc }\left(D_{0}{ }^{\prime}\right)=\operatorname{Min}\left[\left|d_{1}-125\right|\right]
$$

と表現することができる.

さて，このように各諸元を定義したのち，本文で開 発した最適設計システムを働かした。最初にバリアン トアプローチが実行され，データベースに蓄積された 5 種類の代表的固体ホーンの属性諸元のデータを探索 する. このアプローチで, 最適設計値として

$D_{0}{ }^{\prime}=[$ ホーン形状 $=$ 丸文付きステップ形状，材質 $=$ 鋼, $\left.d_{1} / L=0.7, d_{2} / d_{1}=0.4\right]$

を見つけ出した，このときホーンの直径は $d_{1}=122.6$

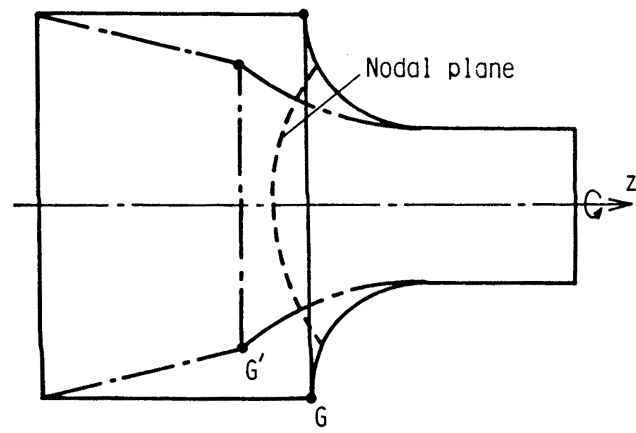

Fig. 4 Variation of solid horns depending on movement of the point $\mathrm{G}$

mmである.

\section{4 ジェネラティブアプローチ}

3.4.1 問題点と創造的一解決法

3.3 節のバリアントアプローチにより設計された丸 久付きステップ形固体ホーンの形状を, 図 4 に実線で 示す。このホーンは与えられた設計仕様を満足する.

しかし，このホーンを実用するとき，ホーンの支持位 置が問題となる。つ方，ホーンは一般に，ホーン表 面上の振動節の位置を支持体で支持して使用される. ところが，この設計されたホーンの振動節は，図4 に 破線で示す振動節面（振動節よりなる面）を見ると， ホーンの丸反部上に存在することがわかる.このため, 支持体による支持が困難となり, ホーンの性能を発揮 することができなくなる。

そこで，本文では，この問題に対して次のような工 夫で,一つの解決を行った。つまり, 図4 中の点 $G を$, 例えば点 $\mathrm{G}^{\prime}$ に移動して, 点 $\mathrm{G} か ゙$ 振動節になるように する.このようにすれば，点 $\mathrm{G}$ を支持することにより， ホーンの支持が容易で確実となり, ホーンの性能を十 分発揮することができる，以下に，本最適設計システ ムによる設計過程を述べる.

3.4 .2 形状関数の設定

点 $\mathrm{G}$ を移動させたときの固体ホーンの形状関数 $g(z)$ を次のように設定する. 図5 亿扔いて点 Gの座 標を $\mathrm{G}(d / 2, l)$ とすると，

点 $\mathrm{F}-\mathrm{G}$ 間は直線：

$$
r=\left\{\left(d-d_{1}\right) / 2 l\right\} z+d_{1} / 2
$$

点 $\mathrm{G}-\mathrm{H}$ 間少円：

$$
(r-R)^{2}+\left\{z-\left(L+d_{1}-d_{2}\right) / 2\right\}^{2}=\left(d_{2} / 2-R\right)^{2}
$$

ただし，

$$
R=\left(d+d_{2}\right) / 4+\left(2 l-L-d_{1}+d_{2}\right)^{2} /\left\{4\left(d-d_{2}\right)\right\}
$$

点 $\mathrm{H}-\mathrm{I}$ 間は直線 :

$$
r=d_{2} / 2
$$

なる方程式で記述することができる. 


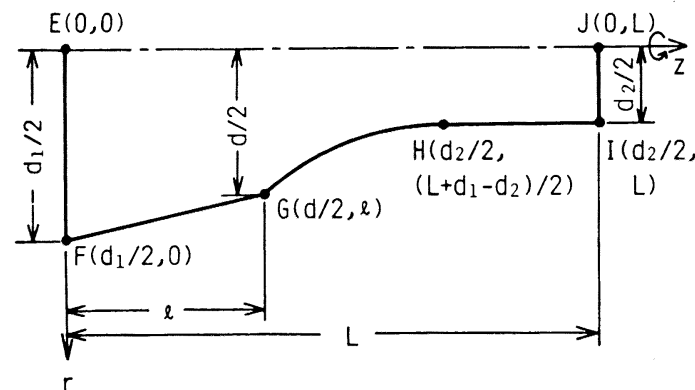

Fig. 5 Geometry of a solid horn to decide an optimal shape

\section{4 .3 各諸元の再設定}

点 $\mathrm{G}$ を振動節にする設計では, 次の事項を考慮して 各諸元を再設定しなければならない，すなわち，(イ） 点 $\mathrm{G}$ が振動節（軸方向振動変位成分が零の位置）にな ること, (口) 第一次固有振動数の值が 3.3 節で得た丸 み付きステップ形ホーンのその值に近いこと, (八) 最 大主応力の值が 3.3 節で得た丸又付きステップ形のそ れより小さいこと，であるまた，実際の設計変数は 点 $\mathrm{G}$ の座標を無次元化した変数 $\left(d / d_{1}, l / L\right)$ を使用 する.

以下に各諸元を再設定する：

設計諸元 $D=\left[g(z)\right.$, 材質, $d_{1} / L, d_{2} / d_{1}, d / d_{1}, l /$ L]

制約諸元 $C=\left[\begin{array}{lll}d_{1} / L, & d_{2} / d_{1}, & d / d_{1},\end{array}, / L, \alpha L, d_{1}\right.$, $\left|V_{1} / V_{0}\right|,\left|V_{\mathrm{S}} / V_{0}-1\right|,\left|V_{\mathrm{T}} / V_{1}-1\right|, V_{z}$, $\left.P_{\mathrm{M}}\right]$

ここで, $V_{z}$ は点 $\mathrm{G}$ の $z$ 方向変位である.

また，制約条件式は，

I $d_{1} / L=0.7, d_{2} / d_{1}=0.4,0.4 \leqq d / d_{1} \leqq 1.0,0 \leqq$ $l / L \leqq 0.5$

II. a) 太い端面のピストン運動性 $\left|V_{\mathrm{S}} / V_{0}-1\right| \leqq$ 0.5 , 細い端面のピストン運動性 $\left|V_{\mathrm{T}} / V_{1}-1\right| \leqq$ 0.5, b) $3 \leqq$ 振幅拡大率 $\left|V_{1} / V_{0}\right| \leqq 4$, c) 点 $\mathrm{G}$ の $z$ 方向変位 $\left|V_{z}\right| \leqq 0.5$, d) 第 1 次固有振動数の 差 $\left|\alpha L-\alpha_{0} L\right| \leqq 0.2$, e) 最大主応力 $P_{\mathrm{M}} \leqq P_{\mathrm{M} 0}$ である。

ただし， $\alpha_{0} L お$ よび $P_{\mathrm{M} 0}$ は, 3.3 節で設計された丸み 付きステップ形ホーンの第 1 次固有振動数拈よび最大 主応力を示す。設計目標は, 点 $\mathrm{G} か ゙$ 振動節になること であるから, 目標諸元 $A=\left[\left|V_{z}\right|\right]$ であり, 式 (5)に示 寸目標仕様の定式化は,

$$
\mathrm{fc}\left(D_{0}\right)=\operatorname{Min}\left[\left|V_{z}\right|\right]
$$

と表現することができる.このように各諸元を定義し たのち, 本最適設計システムのジェネラティブアプ ローチを働かせる，点 $\mathrm{G} の$ 移動に対して生ずる固体

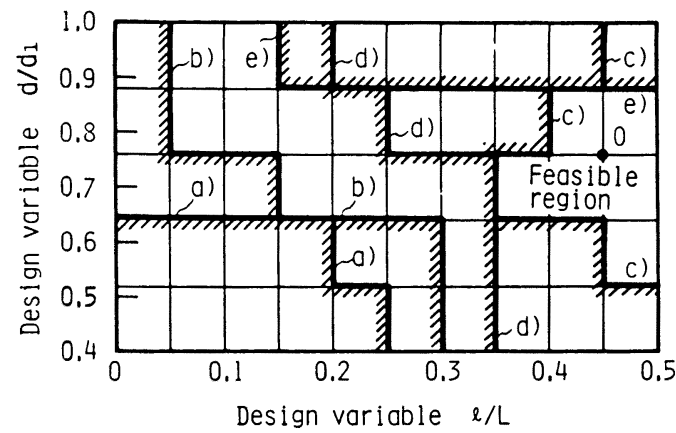

Fig. 6 Feasible region of design variables Small letters a) $\sim$ e) indicate respectively constrained conditions II in the section 3.4 .3

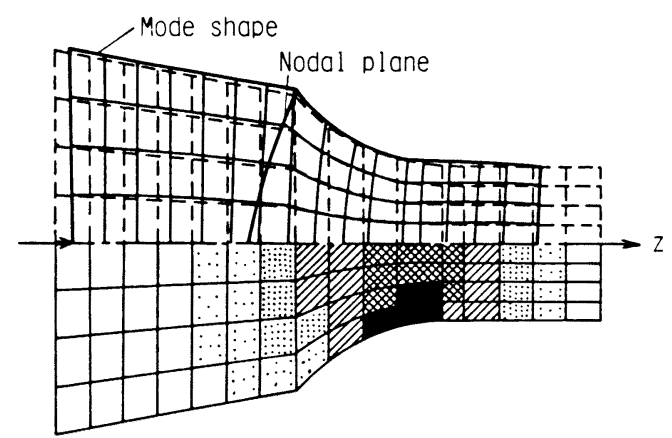

Principal stress distribution

Ranking of non-dimensional principal stress

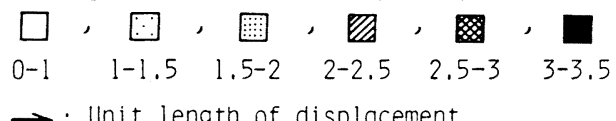

Fig. 7 Displacement and stress distributions of the optimal solid horn

ホーンの形状モデルに対して、データベース中の自動 要素分割プログラムにより要素分割が行われ，各節点 座標が求められ, FEM 専用プログラムが働く。

3.4 .4 設計結果

ジェネラティブアプローチの結果, 最適設計值 $D_{0}=$ $\left(g_{0}(z)\right.$, 材 質 $=$ 鋼, $d_{1} / L=0.7, d_{2} / d_{1}=0.4, d / d_{1}=$ $0.76, l / L=0.45]$ を得た. ただし, 形状関数 $g_{0}(z)$ は, 点 $\mathrm{FG}$ 間: $r=-0.1867 z+0.5 d_{1}$, 点 $\mathrm{GH}$ 間 : $(r-$ $\left.0.6732 d_{1}\right)^{2}+\left(z-1.0143 d_{1}\right)^{2}=0.2237 d_{1}^{2}$, 点 HI 間 : $r=0.2 d_{1}$ なる方程式となる. このジェネラティブア プローチでの最適設計値探索の結果を図 6 に示す。設 計变数 $\left(d / d_{1}, l / L\right)$ よりなる設計平面を図 6 のように 決め, それぞれの制約条件 (3.4.3 項で述べた, 制約条 件 II. a)〜e）を満たす領域を図示する（境界線上は制 約条件を満足する）とともにこれらの制約条件をす べて満たす制約領域（Feasible region）を図示する. 


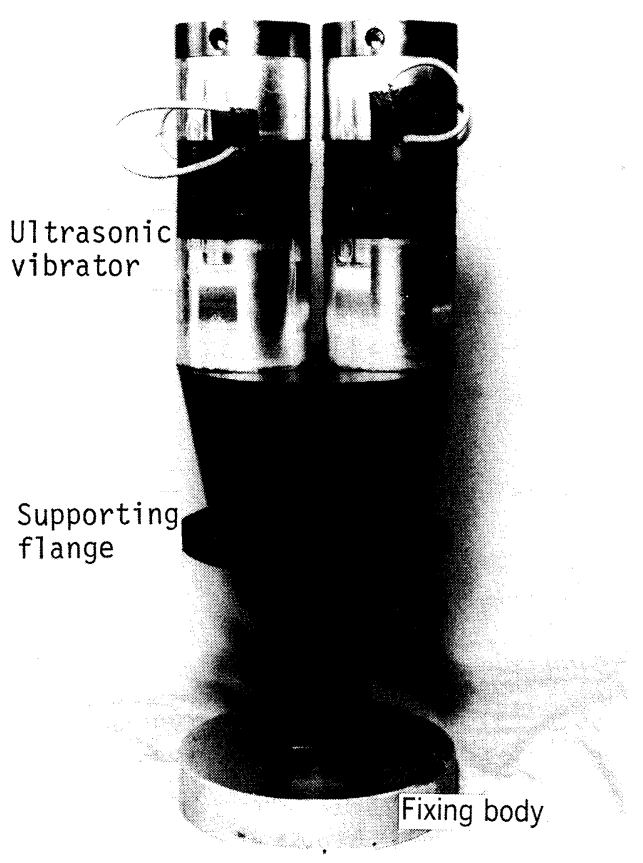

Fig. 8 High-intensity ultrasonic system produced

この制約領域内で目標仕様を満たす最適設計值 $D_{0}$ が 最適化プログラムにより自動的に点 $\mathrm{O}$ として求めら れる。

図 7 は設計された固体ホーンの変位分布（中心線の 上部) および応力分布 (中心線の下部) を示す。振動 時, ホーンの太い端面と細い端面はピストン運動して おり，振幅拡大率は3.9 であり，ホーン表面の振動節 が点 $\mathrm{G}$ にあることを示している. 李た, 最大主応力は, $P_{\mathrm{M} 0}=3.40$ に対して $P_{\mathrm{M}}=3.39$ であり，応力分布斗集 中応力が働かない良い分布を示している.

\section{5 設計值に基づく製作}

設計された固体ホーンの寸法は， $L=176.9 \mathrm{~mm}$, $d_{1}=123.9 \mathrm{~mm}, d_{2}=49.6 \mathrm{~mm}, d=94.2 \mathrm{~mm}, l=79.6$ $\mathrm{mm}$ と決定される.

図 8 は，設計した固体ホーンを実際に製作し，望み の強力超音波振動系を構成した写真を示す。出力 2.5
$\mathrm{kW}$ 用の超音波振動子が固体ホーンの太い端面に2 個 接続され, 円形板上に固定されている。 また，振動節 となる点 $\mathrm{G}$ には支持用フランジが付加されている.こ の振動系の共振周波数は設計值 $15.0 \mathrm{kHz}$ に対して実 測值 $14.7 \mathrm{kHz}$ であり, また, 振幅拡大率は 3.9 に対 して 3.7 を示し，設計值と央測值とが良く一致した。 この振動系は, 最大出力 $5 \mathrm{~kW}$, 細い端面の許容振幅 25 $\mu \mathrm{m}$ として，各種の強力超音波応用機器に使用するこ とができ，本最適設計システムの俸用性を確認するこ とができた。

\section{4.む す び}

以上, 本文では, 強力超音波振動系の最適な設計を 短時間で行らために, 最適設計システムの開発を行っ た.このことを次の 3 点にまとめて記す。

(1) '既に開発した振動解析専用 FEM プログラム を使用する設計法の定式化を行い，この定式化に 基づいて最適化アルゴリズムを提案し, 最適化ブ ログラムを開発した。

（2）過去に蓄積されたデータより最適設計值を求 めるバリアントアプローチと, 設計者の創意工夫 を簡単に取り入れることができるジェネラティブ アプローチとよりなる最適設計システムを開発し た。

（3）この設計システムを適用して, 従来試行錯誤で しか設計できなかった直径の太い固体ホーンの最 適設計を短時間で行らことができた。そして，実 際に試作した結果, 十分実用できることがわかり， 本最適設計システムが強力超音波振動系の設計に 十分活用できることを確認した。

\section{参 考 文 献}

1) 例えば, 山田善一, 大久保禎二: 最適構造設計, 丸善 1983 第 II 部.

2）清水弘幸, 佐田登志夫: 強力超音波用振動系の振動解析法 およびその検証, 精密工学会誌, 54, 1 (1988) 177 .

3）沖野教郎：自動設計の方法論, 養賢堂（1982）第 1 章.

4）清水弘幸, 加藤健一：超音波用エキスボーネンシャル形固 体ホーンの有限要素法による解析, 日本音響学会誌, 34 , 4 (1978) 248. 